Review

\title{
Unveiling changes in the landscape of patient populations in cancer early drug development
}

\author{
Cinta Hierro ${ }^{1}$, Analía Azaro ${ }^{1}$, Guillem Argilés ${ }^{1}$, Elena Elez ${ }^{1}$, Patricia Gómez ${ }^{1}$, Joan \\ Carles $^{1}$ and Jordi Rodon ${ }^{1}$ \\ ${ }^{1}$ Department of Medical Oncology, Vall d'Hebron University Hospital, Vall d'Hebron Institute of Oncology, Barcelona, Spain \\ Correspondence to: Jordi Rodon, email: jrodon@vhio.net \\ Keywords: molecularly targeted agents, patient populations, window-of-opportunity, healthy volunteer, phase 0 \\ Received: May 03, $2016 \quad$ Accepted: October 26, $2016 \quad$ Published: November 09, 2016
}

\section{ABSTRACT}

The introduction of new Molecularly Targeted Agents (MTA) has changed the landscape in Early Drug Development (EDD) over the last two decades, leading to an improvement in clinical trial design. Previous Phase 1 (Ph1) studies with cytotoxics focused on safety objectives, only recruiting heavily pre-treated cancer patients, have been left behind. In this review, we will illustrate the slow although unstoppable change that has increasingly been observed in those populations candidate to participate in EDD trials with the advent of MTA. As more evidence regarding oncogene addiction becomes available, molecular-biomarker driven selection has been implemented among Molecularly-Selected Population (MSP) studies. New WindowOf-Opportunity (WOO) and Phase 0 (PhO) studies have been developed in order to assess whether a MTA produces the hypothetical proposed biological effect. The rising need of getting early pharmacokinetics and pharmacodynamics data has led to the conduction of Healthy Volunteer (HV) studies, in part favoured for the particular and different toxicity profile of these MTA. However, several challenges will need to be addressed in order to boost the implementation of these new clinical trial designs in the forthcoming years. Among the problems to overcome, we would highlight a better coordination effort between centers for ensuring adequate patient accrual among small patient populations and a deepening into the ethics implied in enrolling patients in studies with no therapeutic intent. However, these tribulations will be certainly compensated by the possibility of opening a new horizon of treatment for diseases with dismal prognosis.

\section{INTRODUCTION}

Over the past two decades, with the advent of new Molecularly Targeted Agents (MTA), cancer research has shifted from standard chemotherapies to the selective inhibition of signaling pathways. However, while some of these drugs have offered a significant breakthrough, new insights into the tumor biology and drug development are still required to further delineate rational therapeutic strategies [1]. Phase $1(\mathrm{Ph} 1)$ trials with cytotoxics are mainly focused on safety. Traditionally, first-in-human (FIH) studies were designed with a $3+3$ dose escalation based on acute toxicities. Considering risks and limited efficacy, only heavily pre-treated cancer patients with no standard effective therapies were considered candidates. This dose-toxicity model, though, has shown to be not so effective for testing MTA.
The introduction of MTA has changed the landscape in Early Drug Development (EDD) and subsequently, the clinical trial design. Molecular biomarker-driven selection of patients has progressively been incorporated, as more evidence regarding oncogene addiction is available [2]. New dose escalation strategies are followed now, using dose recommendation methods that help in decision making by providing the probability of toxicities or by incorporating chronic toxicities [3, 4]. Also, there has been a better integration of human pharmacokinetics (PK) and pharmacodynamics (PD). In fact, several new trial designs can be now successfully implemented in the EDD process further to the classical 3+3 design, such as the accelerated titration design (ATD) and continual reassessment method (CRM) [4]. This new designs take advantage of incorporating supplementary endpoints that help to further characterize the MTA in terms of efficacy (mechanism of 
Table 1: Some relevant approved MTA developed with and without a pre-specified Molecularly-Selected Population (MSP).

\begin{tabular}{|c|c|c|c|c|c|c|c|}
\hline $\begin{array}{l}\text { Family of } \\
\text { MTA }\end{array}$ & MTA & Target & $\begin{array}{l}\text { Genetic alteration } \\
\text { as inclusion criteria } \\
\text { in } P h 1\end{array}$ & $\begin{array}{c}\text { Early signs of } \\
\text { efficacy in Ph1 }\end{array}$ & Ref & $\begin{array}{l}\text { Metastatic } \\
\text { tumor type }\end{array}$ & \begin{tabular}{|l} 
FDA \\
approval \\
study
\end{tabular} \\
\hline \multirow{2}{*}{ Anti-HER2 } & lapatinib & $\begin{array}{l}\text { EGFR1 } \\
\text { HER2 }\end{array}$ & $\begin{array}{l}\text { Yes, EGFR1/ } \\
\text { HER2over }\end{array}$ & $\begin{array}{c}\text { No CR } \\
4 \text { PR (BC HER2+ } \\
\text { TTZresist) }\end{array}$ & [60] & BC HER2+ & $\mathrm{Ph} 3$ [61] \\
\hline & pertuzumab & HER2 & No & $\begin{array}{c}\text { No CR } \\
2 \text { PR (1 OC, } 1 \text { PC) } \\
\end{array}$ & [62] & BC HER2+ & $\mathrm{Ph} 3$ [63] \\
\hline $\begin{array}{l}\text { Multi-tyrosine } \\
\text { kinase } \\
\text { inhibitors }\end{array}$ & imatinib & $\begin{array}{l}\text { BCR-ABL } \\
\text { c-KIT }\end{array}$ & $\begin{array}{c}\text { No. } \\
\text { Study only in soft- } \\
\text { tissue sarcomas. } \\
\text { All enrolled GIST } \\
\text { c-KITover }\end{array}$ & $\begin{array}{c}\text { No CR } \\
16 \text { PR (all GISTs) }\end{array}$ & [64] & GIST & $\mathrm{Ph} 3$ [65-67] \\
\hline \multirow{2}{*}{$\begin{array}{l}\text { EGFR } \\
\text { inhibitors }\end{array}$} & erlotinib & EGFR & No & $\begin{array}{c}1 \mathrm{CR}(\mathrm{RCC}) \\
1 \mathrm{PR}(\mathrm{CRC}) \\
6 \mathrm{SD}\end{array}$ & [68] & $\begin{array}{c}\text { AdeNSCLC } \\
\text { EGFRmut }\end{array}$ & $\mathrm{Ph} 3$ [69] \\
\hline & gefitinib & EGFR & No & $\begin{array}{c}\text { No CR } \\
\text { No PR } \\
7 \text { SD } \\
\end{array}$ & [16] & $\begin{array}{c}\text { AdeNSCLC } \\
\text { EGFRmut }\end{array}$ & $\mathrm{Ph} 3$ [70] \\
\hline $\begin{array}{l}\text { PARP } \\
\text { inhibitors }\end{array}$ & olaparib & PARP & $\begin{array}{l}\text { No, expansion } \\
\text { enriched with } \\
\text { BRCAmut }\end{array}$ & $\begin{array}{c}20 \mathrm{CR} / \mathrm{PR}(\mathrm{OC}) \\
3 \mathrm{SD}\end{array}$ & [71] & $\begin{array}{l}\text { OC } \\
\text { BRCAmut }\end{array}$ & $\mathrm{Ph} 2$ [72] \\
\hline \multirow{2}{*}{$\begin{array}{l}\text { BRAF } \\
\text { inhibitors }\end{array}$} & vemurafenib & BRAF & $\begin{array}{l}\text { No, expansion } \\
\text { enriched with M } \\
\text { BRAFmut }\end{array}$ & $\begin{array}{c}3 \mathrm{CR} \\
34 \text { PR (M) }\end{array}$ & [73] & \multirow{2}{*}{$\begin{array}{l}\text { M V600E } \\
\text { BRAFmut }\end{array}$} & Ph3 [74] \\
\hline & dabrafenib & BRAF & $\begin{array}{l}\text { No, later on only } \\
\text { BRAFmut tumors }\end{array}$ & \begin{tabular}{|c} 
No CR \\
20 PR (18 M, 1 \\
NSCLC, 1 CRC) \\
\end{tabular} & [17] & & $\mathrm{Ph} 3$ [75] \\
\hline \multirow[b]{2}{*}{$\begin{array}{l}\text { ALK } \\
\text { inhibitors }\end{array}$} & crizotinib & $\begin{array}{l}\text { ALK } \\
\text { MET }\end{array}$ & $\begin{array}{c}\text { No, expansion } \\
\text { enriched with } \\
\text { NSCLC ALKtransl }\end{array}$ & $\begin{array}{c}3 \text { CR } \\
84 \text { PR (NSCLC } \\
\text { ALKtransl) }\end{array}$ & [18] & \multirow[b]{2}{*}{$\begin{array}{c}\text { AdeNSCLC } \\
\text { ALKtransl }\end{array}$} & $\mathrm{Ph} 2$ [22] \\
\hline & ceritinib & $\begin{array}{l}\text { ALK } \\
\text { GF-1 }\end{array}$ & $\begin{array}{l}\text { Yes, ALKtransl } \\
\text { tumors }\end{array}$ & $\begin{array}{c}1 \text { CR NSCLC } \\
67 \text { PR (65 } \\
\text { NSCLC, } 1 \text { ALCL, } \\
1 \text { myofibroblastic } \\
\text { tumor) }\end{array}$ & [23] & & Ph1 [23] \\
\hline
\end{tabular}

Abbreviations: MTA (Molecularly Targeted Agents); HER2 (Human Epidermal growth factor Receptor 2); EGFR (Epidermal Growth Factor Receptor); ALK (Anaplastic Lymphoma Kinase); PARP (Poly [ADP-ribose] polymerase); BRCA (BReast CAncer gene); over (overexpression); ampl (amplification); mut (mutation); transl (translocation); BC (Breast Cancer); HR+ (Hormone Receptor positive); TTZresist (TrasTuZumab resistant); OC (Ovarian Cancer); PC (Pancreatic Carcinoma); GIST (GastroIntestinal Stromal Tumors); RCC (Renal Clear Cell carcinomas); CRC (ColoRectal Carcinomas); M (Melanomas); NSCLC (Non Small Cell Lung Cancer); Ade (Adenocarcinoma); ALCL (Anaplastic Large-Cell Lymphoma); CR (Complete Response); PR (Partial Response); SD (Stable Disease); Ph (Phase).

action -MoA-/PD biomarkers) on top of the traditional toxicity endpoints, and also allow a fine-tune assessment of the safety profile by evaluating the late-onset toxicities and not only the acute ones. Finally, there is increasing evidence that some of these MTA present a class-specific toxicity, related to their "on-target" effect (e.g.: fibroblast growth factor receptor inhibitors and hyperphosphatemia) [5]. As target inhibition can cause toxicity leading to treatment interruptions, the consideration of new optimal schedules while maintaining the target inhibition-related anti-tumor efficacy has become a critical key point [5].

Within this context, we are progressively witnessing an unprecedented shift towards a completely different population profile in EDD. To clarify in which selected biological context the drug works, some trials include now Molecularly Selected Patient (MSP) populations [2]. Despite the efforts, there are still scarce predictive biomarkers, meaning that a rising need to determine upfront whether a MTA produces the hypothetical biological effect exists. New Window-Of-Opportunity (WOO) studies [6] and Phase 0 studies (Ph0) [7, 8] have been developed in order to fill in the gap. MTA have revolutionized previous toxicity concepts, as may not have single direct dose-response relationship, with higher doses lacking of further benefit after a biological effective dose has been reached [9]. Longstanding mild toxicity is commonly seen instead of acute intense toxicities, with neither teratogenicity nor carcinogenic effects. 
Table 2: Some ongoing early clinical trials testing MTA in Molecularly-Selected Populations (MSP).

\begin{tabular}{|c|c|c|c|c|c|c|c|}
\hline Family of MTA & MTA & Target & $\begin{array}{l}\text { Genetic alteration as } \\
\text { inclusion criteria in Ph1 }\end{array}$ & Early signs of efficacy in Ph1 & Ref & $\begin{array}{l}\text { Ongoing } \\
\text { studies }\end{array}$ & $\begin{array}{l}\text { ClinicalTrials.gov } \\
\text { identifier }\end{array}$ \\
\hline \multirow{3}{*}{ FGFR inhibitors } & AZD4547 & FGFR $1 / 2 / 3$ & $\begin{array}{l}\text { Yes, since escalation, } \\
\text { FGFR1/2ampl }\end{array}$ & $\begin{array}{l}\text { No CR } \\
2 \text { PR (SqNSCLC FGFR1ampl, } \\
\text { GC FGFR2ampl) } \\
\text { SD (BC, GOJ/GC SqNSCL, } \\
\text { UC FGFRampl) }\end{array}$ & {$[76-78]$} & $\begin{array}{l}\text { Ph1 } \\
\text { Ph2 NSCLC } \\
\text { Ph2 GC/GOJ } \\
\text { Ph2 BC }\end{array}$ & $\begin{array}{l}\text { NCT00979134 } \\
\text { NCT01824901 } \\
\text { NCT01457846 } \\
\text { NCT01202591 }\end{array}$ \\
\hline & BGJ398 & FGFR1/2/3 & $\begin{array}{l}\text { Yes, since escalation, any } \\
\text { FGFRalt }\end{array}$ & $\begin{array}{l}\text { No CR } \\
6 \text { PR (4 UC FGFR3mut, } 2 \\
\text { SqNSCLC FGFR1ampl) } \\
\text { SD (BC FGFR1ampl, ABTC } \\
\text { FGFR2transl) }\end{array}$ & [79] & $\begin{array}{l}\text { Ph1 } \\
\text { Ph2 ABTC }\end{array}$ & $\begin{array}{l}\text { NCT01004224 } \\
\text { NCT02160041 }\end{array}$ \\
\hline & $\begin{array}{l}\text { JNJ-42756493 } \\
\text { (erdafitinib) }\end{array}$ & FGFR $1 / 2 / 3 / 4$ & $\begin{array}{l}\text { Yes, since escalation, any } \\
\text { FGFRalt }\end{array}$ & $\begin{array}{l}\text { 1 CR (UC FGFR2trunc) } \\
1 \text { PR (UC FGFR3transl) } \\
\text { SD (lung, CS, BC } \\
\text { FGFRlampl) }\end{array}$ & {$[80]$} & $\begin{array}{l}\mathrm{Ph} 1 \\
\mathrm{Ph} 2 \mathrm{UC}\end{array}$ & $\begin{array}{l}\text { NCT01703481 } \\
\text { NCT02365597 }\end{array}$ \\
\hline \multirow{2}{*}{ MET inhibitors } & $\begin{array}{l}\text { INC280 } \\
\text { (capmatinib) }\end{array}$ & MET & $\begin{array}{l}\text { Yes, since escalation, } \\
\text { METalt }\end{array}$ & $\begin{array}{l}\text { No CR } \\
\text { No PR } \\
\text { SD (CRC, HCC, lung) }\end{array}$ & {$[81]$} & $\begin{array}{l}\mathrm{Ph} 1 \\
\mathrm{Ph} 2 \mathrm{NSCLC}\end{array}$ & $\begin{array}{l}\text { NCT01324479 } \\
\text { NCT01911507 }\end{array}$ \\
\hline & SAR125844 & MET & $\begin{array}{l}\text { Yes, since escalation, } \\
\text { METalt }\end{array}$ & $\begin{array}{l}\text { No CR } \\
1 \text { PR (lung cMETampl) } \\
\text { SD (not specified) }\end{array}$ & {$[82]$} & $\begin{array}{l}\text { Ph1 } \\
\text { Ph2 NSCLC }\end{array}$ & $\begin{array}{l}\text { NCT01391533 } \\
\text { NCT02435121 } \\
\end{array}$ \\
\hline EGFR inhibitors & $\begin{array}{l}\text { PF-00299804 } \\
\text { (dacomitinib) }\end{array}$ & Pan-HER & $\begin{array}{l}\text { Yes, since expansion, } \\
\text { EGFRalt }\end{array}$ & $\begin{array}{l}\text { No CR } \\
4 \text { PR (AdeNSCLC) } \\
\text { SD (AdeNSCLC, others) }\end{array}$ & {$[83]$} & $\begin{array}{l}\text { Ph1 } \\
\text { Ph2 OEC } \\
\text { Ph3 NSCLC }\end{array}$ & $\begin{array}{l}\text { NCT00225121 } \\
\text { NCT01608021 } \\
\text { NCT01000025 }\end{array}$ \\
\hline $\begin{array}{l}\text { Multi-tyrosine kinase } \\
\text { inhibitors }\end{array}$ & $\begin{array}{l}\text { E3810 } \\
\text { (lucitanib) }\end{array}$ & $\begin{array}{l}\text { VEGFR } 1 / 2 / 3 \\
\text { PDGFRa/b } \\
\text { FGFR } 1 / 2 / 3\end{array}$ & $\begin{array}{l}\text { Yes, since expansion, } \\
\text { cohort FGFR1/11q ampl }\end{array}$ & $\begin{array}{|ll|}3 \text { CR (2 MTC, 1 RCC) } & \\
\text { PR (NSCLC and } & \text { BC } \\
\text { FGFR1/11q ampl) } & \\
\text { SD (NSCLC and } & \text { BC } \\
\text { FGFR1/1 } 1 \text { ampl, others) } & \end{array}$ & {$[84]$} & $\begin{array}{l}\text { Ph1 } \\
\text { Ph2 BC HR+ } \\
\text { Ph2 NSCLC }\end{array}$ & $\begin{array}{l}\text { NCT01283945 } \\
\text { NCT02053636 } \\
\text { NCT02109016 }\end{array}$ \\
\hline \multirow{2}{*}{$\begin{array}{l}\text { PIK3CA/ } \\
\text { mTOR } \\
\text { inhibitors }\end{array}$} & $\begin{array}{l}\text { BYL719 } \\
\text { (alpelisib) }\end{array}$ & PIK3CAa & $\begin{array}{l}\text { Yes, since escalation, } \\
\text { PIK3CAalt }\end{array}$ & $\begin{array}{l}\text { No CR } \\
15 \text { PR (2 BC HR+ PIK3CAalt) }\end{array}$ & {$[85]$} & $\begin{array}{l}\mathrm{Ph} 1 \\
\mathrm{Ph} 2 \mathrm{BC} \mathrm{HR}+\end{array}$ & $\begin{array}{l}\text { NCT01219699 } \\
\text { NCT02058381 }\end{array}$ \\
\hline & $\begin{array}{l}\text { BKM120 } \\
\text { (buparlisib) }\end{array}$ & $\begin{array}{l}\text { Pan-Class I } \\
\text { PIK3CA }\end{array}$ & $\begin{array}{l}\text { Yes, since expansion, } \\
\text { cohort PIK3CA/PTENalt }\end{array}$ & $\begin{array}{l}\text { No CR } \\
4 \text { PR (1 confirmed TBNC } \\
\text { PI3KCAmut, } 1 \text { PGC, BC } \\
\text { HR+,EH) }\end{array}$ & [86] & $\begin{array}{l}\mathrm{Ph} 1 \\
\mathrm{Ph} 2 \mathrm{TBNC}\end{array}$ & $\begin{array}{l}\text { NCT01068483 } \\
\text { NCT01629615 }\end{array}$ \\
\hline \multirow{2}{*}{$\begin{array}{l}\text { MAPK } \\
\text { inhibitors }\end{array}$} & $\begin{array}{l}\text { LGX818 } \\
\text { (encorafenib) }\end{array}$ & BRAF & $\begin{array}{l}\text { Yes, since escalation, } \\
\text { BRAF V600mut }\end{array}$ & $\begin{array}{l}\text { No CR } \\
13 \text { PR (M BRAF V600mut), } \\
12 \text { SD (CRC BRAF V600mut) }\end{array}$ & {$[87,88]$} & $\mathrm{Ph} 1$ & NCT01436656 \\
\hline & $\begin{array}{l}\text { MEK162 } \\
\text { (binimetinib) }\end{array}$ & MEK $1 / 2$ & $\begin{array}{l}\text { Yes, since expansion, } \\
\text { KRAS and BRAFmut }\end{array}$ & $\begin{array}{l}\text { No CR } \\
1 \text { PR (ABTC NRASmut), } \\
9 \text { SD }\end{array}$ & [89] & $\mathrm{Ph} 1$ & NCT00959127 \\
\hline \multirow[t]{2}{*}{ PARP inhibitors } & olaparib & PARP & $\begin{array}{l}\text { No, expansion enriched } \\
\text { BRCAmut }\end{array}$ & $\begin{array}{l}1 \mathrm{CR}(\mathrm{BC}) \\
21 \mathrm{PR}(15 \text { OC, } 6 \text { BC) }\end{array}$ & [90] & $\begin{array}{l}\mathrm{Ph} 1 \mathrm{BC} / \mathrm{OC} \\
\mathrm{Ph} 2 \mathrm{TBNC} \\
\mathrm{Ph} 3 \mathrm{OC}\end{array}$ & $\begin{array}{l}\text { NCT01445419 } \\
\text { NCT02681562 } \\
\text { NCT02446600 }\end{array}$ \\
\hline & talazoparib & PARP & $\begin{array}{l}\text { Yes, since expansion, } \\
\text { BRCAmut }\end{array}$ & $\begin{array}{l}\text { No CR } \\
13 \text { PR (11 OC/peritoneal, } 2 \text { BC } \\
\text { BRCAmut) }\end{array}$ & [91] & $\begin{array}{l}\mathrm{Ph} 1 \\
\mathrm{Ph} 2 \mathrm{BC}\end{array}$ & $\begin{array}{l}\text { NCT01286987 } \\
\text { NCT02034916 }\end{array}$ \\
\hline \multirow[b]{2}{*}{ ROS/ALK inhibitors } & $\mathrm{X}-396$ & ALK & $\begin{array}{l}\text { Yes, since escalation, } \\
\text { ALKalt }\end{array}$ & $\begin{array}{l}\text { No CR } \\
5 \text { PR (NSCLC ALKtransl) } \\
5 \text { SD (NSCLC ALKtransl) }\end{array}$ & {$[92]$} & $\mathrm{Ph} 1$ & NCT01625234 \\
\hline & $\begin{array}{l}\text { RXDX-101 } \\
\text { (entrectinib) }\end{array}$ & $\begin{array}{l}\text { Pan-TrKA/B/C } \\
\text { ROS1 } \\
\text { ALK }\end{array}$ & $\begin{array}{l}\text { Yes, since escalation, } \\
\text { TrKA/B/C, ROS1 and } \\
\text { ALKalt }\end{array}$ & $\begin{array}{l}\text { No CR } \\
4 \text { PR (1 CRC TrKA+, } 1 \\
\text { NSCLC ROS1+ and NSCLC } \\
\text { ALK+, } 1 \text { NB ALK }+ \text { ) } \\
2 \text { SD (NSCLC ALK+, PC } \\
\text { ROS1+) }\end{array}$ & [93] & $\mathrm{Ph} 1$ & NCT02097810 \\
\hline
\end{tabular}

Abbreviations: MTA (Molecularly Targeted Agents); HER 2 (Human Epidermal growth factor Receptor) 2; EGFR (Epidermal Growth Factor Receptor); ALK (Anaplastic Lymphoma Kinase); FGFR (Fibroblast Growth Factor Receptor); ampl (amplification); mut (mutation); trunc (truncation); transl (translocation); alt (alteration); HCC (HepatoCarcinoma); NSCLC (Non Small Cell Lung Cancer); Ade (Adenocarcinoma); Sq (Squamous); ALCL (Anaplastic Large-Cell Lymphoma); BC (Breast Cancer); HR+ (Hormone Receptor positive); CS (ChondroSarcoma); OEC (OEsophageal Carcinoma); GOJ (GastroesOphageal Junction carcinoma); GC (Gastric Cancer); UC (Urothelial Carcinoma); MTC (Medullary Thyroid Carcinoma); RCC (Renal Clear Cell carcinoma); M (Melanoma); CRC (ColoRectal Cancer); ABTC (Advanced Biliary Tract Carcinoma); OC (Ovarian Carcinoma); TBNC (Triple Breast Negative Cancer); PGC (Parotid Gland Carcinoma); EH (Epithelioid Hemangiothelioma); NB (NeuroBlastoma); PC (Pancreatic Carcinoma); CR (Complete Response); PR (Partial Response); SD (Stable Disease); VEGFR (Vascular Endothelial Growth Factor Receptor); PDGFR (Platelet Derived Growth Factor Receptor); TrK (Tropomyosin receptor Kinase); PARP (Poly [ADP-ribose] polymerase); BRCA (BReast CAncer gene); $\mathrm{Ph}(\mathrm{Ph})$. 
Considering their different toxicity profile [10], MTA have favoured the conduction of Healthy Volunteer (HV) studies [11, 12], aiming for PK and PD endpoints.

Based on these premises, we will illustrate the change in the population of patients enrolled in early clinical trials testing MTA.

\section{MOLECULARLY- POPULATION STUDIES}

SELECTED

Some MTA have been already approved despite the fact of not having identified a predictive biomarker to associate their clinical efficacy. Multi-tyrosine kinase inhibitors, such as sorafenib in hepatocarcinoma [13], and sunitinib in renal cancer [14] would fall into this category. But for the majority of these MTA, it has been key in their development to tailor them with molecular aberrations that harbor different tumor types. Therefore, pre-identification of a driver alteration has become mandatory to prescribe these MTA. Overexpression or amplification of HER2 in breast or gastric carcinomas [15], EGFR mutations in lung carcinoma [16], and BRAF mutations in melanoma [17], would be the best examples of tailored tumor-type treatments. One must bear in mind that whilst some of the MTA target molecular alterations that have not been proven to be drivers for any specific disease (e.g. PI3KCA mutations), other MTA target clear defined oncogenic aberrations (e.g. EGFR mutations in non-small cell lung cancer-NSCLC-). The molecular selection of patients will be key in the second case for warranting the success of a MTA in that subset of patients, but less obvious and not mandatory in the first case.

Noteworthy, some MTA have been recently approved after the initial studies showed impressive response rates in subsets of MSP. Interestingly, some of these first MTA were not initially developed for a prespecified MSP, but as the Ph1 was being conducted, early signs of response were noticed in genomically-altered subgroups of patients. The later enrichment confirmed the oncogenic addiction for a specific aberration, which lead to the MTA approval only for those subsets of patients. That is the case of crizotinib for NSCLC with ALK rearrangement [18].

$\mathrm{Ph} 1$ clinical trials have emerged as the most suitable arena for testing the hypothetical relationship between a predictive biomarker and the efficacy of a given drug, driving knowledge in the right direction. The idea for doing this very early in the development of a drug is to test the efficacy in the best-case scenario and for assisting in go-no go decisions [19]. By enriching early $\mathrm{Ph} 1$ trials with patients harboring specific molecular alterations, it could be demonstrated the proof-of-concept hypothesis for the MTA mechanism and encourage its further development [20]. But quite frequently, these markers are not well validated, and to date, they are still used as enrichment biomarkers. Nevertheless, the discovery of robust predictive biomarkers in subsets of patients parallel to the development of MTA, could provide a personalized therapeutic option for cancer patients lacking of standard options. As highlighted before, that was the case with crizotinib, the first-in-class ALK inhibitor, that demonstrated fast and durable responses in metastatic ALK positive NSCLC patients in early $\mathrm{Ph} 1[18,21]$ and $\mathrm{Ph} 2$ [22] trials. These results lead to the accelerated crizotinib-FDA approval after a three-year development programme, and opened the door to the pharmaceutical companies to apply for a Fast Track designation from the regulatory agencies. Recently, the approval of ceritinib for NSCLC with ALK rearrangement after progression to crizotinib, solely based on the results of the $\mathrm{Ph} 1$, has supposed another milestone in the history of EDD in Oncology [23]. This clearly shows that well conducted $\mathrm{Ph} 1$ trials could accelerate the drug development, especially where a drug could fill a void for a poor prognosis orphan disease. This really depends on how well designed are these early clinical trials, specially in terms of wise collection of the generated data in order to prove the MoA of the new MTA and to allow the analysis of statistically meaningful preliminary data. Table 1 depicts some of the most relevant approved MTA. These MTA have been selected in view of the impact that their development represented for the clinical management of these tumor subtypes.

In parallel, we are witnessing the development of new molecular diagnostic techniques alongside to the discovery of new aberrations. This fact has led to a gradually narrowing of the pre-selection criteria for candidate patients. Sometimes, a specific molecular alteration is not a requirement for participating in a study, but throughout the trial, an increasing number of patients with that aberration show response, and this biomarker is later on required for inclusion. In other cases, $\mathrm{Ph} 1$ trials do pre-select patients according to a specific molecular alteration from the early beginning. In both situations, the tactics allows the study to enrich the population, and might help us to early identifying the subgroup of patients who will benefit the most from the MTA. Some of the MTA that are contemporary being developed under strict molecular pre-selection criteria are shown in Table 2.

Recently, the results of a meta-analysis presented by Schwaederle MC. et al [24] showed improved outcomes in patients treated in $\mathrm{Ph} 1$ trials using a biomarkerselection strategy. The analysis of over 13.203 patients demonstrated that a more personalized approach had a statistically improved RR ( $30.6 \%$ versus $4.9 \%, \mathrm{p}<0.0001)$ as well as a better PFS (5.7 months versus 2.9 months, $\mathrm{p}=0.002$ ) compared to the non-personalized option. These data reflect the importance of delineating a better biomarker-selection of patient candidates to participate in early clinical trials developing MTA, as the majority of $\mathrm{Ph} 1$ testing targeted agents in non-selected patients presented trivial responses. 
Table 3: Some ongoing Window-Of-Opportunity (WOO) studies testing MTA in the neo-adjuvant setting.

\begin{tabular}{|c|c|c|c|c|c|c|}
\hline Family of MTA & MTA & Mechanism of action & Endpoints of the study & Subject dose & $\begin{array}{l}\text { Status } \\
\text { (histology) }\end{array}$ & $\begin{array}{l}\text { ClinicalTrials. } \\
\text { gov Identifier } \\
\text { or Reference }\end{array}$ \\
\hline AKT inhibitors & MK-2206 & AKT inhibitor & $\begin{array}{l}\text { To assess pAKT } \\
\text { modulation in tumor tissue. }\end{array}$ & $\begin{array}{l}\text { MK-2206 dose } \\
\text { day }-9 / \text { day }-2\end{array}$ & $\begin{array}{l}\text { Ph2 } \\
\text { (early BC) }\end{array}$ & [94] \\
\hline IGF-IR inhibitors & $\begin{array}{l}\text { CP751871 } \\
\text { (figitumumab) }\end{array}$ & $\begin{array}{l}\text { Monoclonal antibody for } \\
\text { IGF-IR }\end{array}$ & $\begin{array}{l}\text { To assess tumor total } \\
\text { choline changes } \\
\text { determined by MRS. }\end{array}$ & $\begin{array}{l}\text { CP751871 dose day } \\
1 / 22\end{array}$ & $\begin{array}{l}\text { Ph1 withdrawn } \\
\text { (early BC) }\end{array}$ & NCT00635245 \\
\hline IGF-IR & $\begin{array}{l}\text { CP751871 } \\
\text { (figitumumab) }\end{array}$ & $\begin{array}{l}\text { Monoclonal antibody for } \\
\text { IGF-IR }\end{array}$ & $\begin{array}{l}\text { To assess biological RR } \\
\text { (proportion of patients } \\
\text { with inhibition of IGF-IR } \\
\text { expression by IHC). }\end{array}$ & $\begin{array}{l}\text { CP751871 } 20 \mathrm{mg} / \mathrm{kg} \\
\text { every } 3 \mathrm{w} \text { x } 3 \text { cycles }\end{array}$ & $\begin{array}{l}\mathrm{Ph} 2 \\
\text { (early PrC) }\end{array}$ & {$[95]$} \\
\hline mTOR inhibitors & $\begin{array}{l}\begin{array}{l}\text { MK-0646 } \\
\text { (dalotuzumab) }\end{array} \\
\text { with or without } \\
\text { MK-8669 } \\
\text { (ridaforolimus) }\end{array}$ & $\begin{array}{l}\text { Monoclonal antibody for } \\
\text { IGF-IR } \\
\text { mTOR inhibitor }\end{array}$ & $\begin{array}{l}\text { To demonstrate inhibition } \\
\text { of GFS in patients with } \\
\text { high proliferation index. }\end{array}$ & $\begin{array}{l}\text { A) MK-8669 OD x5 } \\
\text { days/week and MK- } \\
0646 \text { once weekly. } \\
\text { B) MK-8669 OD x5 } \\
\text { days/week. } \\
\text { C) MK-0646 once } \\
\text { weekly }\end{array}$ & $\begin{array}{l}\text { Ph1 } \\
\text { (early BC) }\end{array}$ & NCT0 1220570 \\
\hline $\begin{array}{l}\text { Oral anti- } \\
\text { diabetics }\end{array}$ & metformin & $\begin{array}{l}\text { Metabolic signalling } \\
\text { pathway inhibition } \\
\text { (cAMP, protein kinase } \\
\text { A) }\end{array}$ & $\begin{array}{l}\text { To evaluate changes in } \\
\text { proliferation marker }(\mathrm{Ki} 67) \\
\text { in tissues. }\end{array}$ & $\begin{array}{l}\text { Daily dose at bedtime } \\
\text { for } 2 \text { weeks, prior } \\
\text { planned surgery }\end{array}$ & $\begin{array}{l}\text { Ph0 } \\
\text { (early BC or } \\
\text { DCIS) }\end{array}$ & NCT01980823 \\
\hline
\end{tabular}

Abbreviations: MTA (Molecularly Targeted Agents); pAKT (phospho-AKT); IGF-IR (Insulin-like Growth Factor 1 Receptor); MRS (Magnetic Resonance Spectroscopy); Ph (Phase); BC (Breast Cancer); RR (Response Rate); IHC (ImmunoHistoChemistry); PrC (Prostate Cancer); GFS (Growth Factor Signature); OD (Once Daily); DCIS (Ductal breast Carcinoma In Situ).

Of note, analyzing a tumor sample can easily change the selected population. Firstly, where a fresh tumor sample is required, patients deemed not biopsiable might have less chances of trial inclusion. Also, patients are at risk of deteriorating while waiting for a complex biomarker assessment (central review), biasing the trial towards healthier patients, and notice that inadequate or too strict molecular pre-screening criteria may considerably slow down the recruitment. Secondly, patients whose tumor bears the pre-specified alteration may be recruited even if standard therapies have not been exhausted yet, based on increased expectations for response. It is worth noticing that not all patients that are tested positive for the selection biomarker would be finally considered eligible for a trial, therefore molecular selection can sometimes generate false hope for patients. Finally, patients may be excluded based on an insufficiently validated biomarker.

In fact, the identification of suitable biomarkers has become one of the main priorities in parallel with the development of new MTA, although it has proven to be challenging [25]. Predictive biomarkers are patient and/or disease characteristics that can be objectively measured, indicating subgroup of patients who are most likely to benefit from a therapy $[26,27]$. Whenever developing a biomarker, researchers have to keep in mind that a feasible assay should be validated according to a "fit-for-purpose" approach, in order to ensure accuracy and reproducibility of the detection assay [28]. Nevertheless, differences in sample acquisition and processing, assay implementation and analysis across different centers, can be counted as certain of the hurdles to overcome. In addition, knowing the intrinsic tumor heterogeneity [29], it should be considered that a negative biomarker sample does not specifically mean that the patient cannot yet benefit from the study drug.

We are facing an era where there will be increasing evidences that several tumors could be categorized by specific molecular changes that drive their proliferation. The hypothesis that blocking an activated oncogenic pathway will lead to tumor control warrants further efforts to determine biomarkers for facilitating this patient population identification. In our opinion, a better delineation of genomic pre-screening strategies seems to be the right direction for identifying those patients who may achieve greater benefit from an MTA, and could avoid unnecessary toxicities to patients who are less likely to benefit from this drugs, minimizing the risks and developmental costs of highly expensive targeted therapies. However, one should be aware of the level of validation of the selection biomarker and its companion diagnostic assay, before switching the participating patient population towards less pre-treated patients.

\section{WINDOW- OF- OPPORTUNITY STUDIES}

The development of MTA and the need of testing their biological effect have highlighted the convenience of implementing new trial designs, considering that the MTA activity may be shadowed in advanced oncology patients, because of previous cytotoxic resistances, residual toxicities or high tumor burden conferring high intratumor heterogeneity. WOO studies have been considered one of the best scenarios for testing MTA and biomarker development, as patients receive the MTA for a short period of time -concept of window- just before performing the standard treatment. Aiming to evaluate the key target 
Table 4: Examples of Phase 0 (Ph0) studies testing MTA in Oncology.

\begin{tabular}{|c|c|c|c|c|c|c|}
\hline Family of MTA & MTA & $\begin{array}{l}\text { Mechanism of } \\
\text { action }\end{array}$ & Endpoints of the study & Subject dose & $\begin{array}{l}\text { Fulfils } \\
\text { Ph0 } \\
\text { criteria }\end{array}$ & Reference \\
\hline $\begin{array}{l}\text { Cytotoxic agent } \\
\text { radiolabelled with } \\
\text { positron emitting } \\
\text { radioisotopes }\end{array}$ & $\begin{array}{l}\text { carbon-11 } \\
\text { radiolabelled } \\
\text { N-[2- } \\
\text { (dimethylamino) } \\
\text { ethyl]acridine- } \\
\text { 4-carboxamide } \\
\text { (DACA) } \\
\end{array}$ & $\begin{array}{l}\text { 11C-labelled } \\
\text { topoisomerase } \\
\text { I/II inhibitor }\end{array}$ & $\begin{array}{l}\text { To evaluate plasma } \\
\text { PD effects of drugs } \\
\text { using data obtained } \\
\text { during PET studies with } \\
\text { radiolabelled anti-cancer } \\
\text { agents. }\end{array}$ & $\begin{array}{l}\text { DACA at } \\
1 / 1000 \text { th of } \mathrm{Ph} 1 \text {, } \\
\text { as part of Ph0 } \\
\text { micro-dosing } \\
\text { study }\end{array}$ & Yes & [43] \\
\hline $\begin{array}{l}\text { Multi-tyrosine } \\
\text { kinase inhibitor }\end{array}$ & imatinib & $\begin{array}{l}\text { BCR-ABL and } \\
\text { c-KIT } \\
\text { inhibitor }\end{array}$ & $\begin{array}{l}\text { To investigate the } \\
\text { potential use of MS for } \\
\text { studying pharmacology } \\
\text { aspects of imatinib. }\end{array}$ & $\begin{array}{l}\text { Imatinib } 400 \\
\text { mg/d plus } 13.6 \\
\text { kBq of } \\
\text { 14C-imatinib }\end{array}$ & Yes & [44] \\
\hline PARP inhibitor & $\begin{array}{l}\text { ABT-888 } \\
\text { (veliparib) }\end{array}$ & \begin{tabular}{|l|} 
Poly (ADP- \\
ribose) \\
polymerase \\
inhibitor \\
\end{tabular} & $\begin{array}{l}\text { Proof-of-mechanism of } \\
\text { action. } \\
\text { To evaluate PARP levels } \\
\text { after dosing (PD effect). }\end{array}$ & $\begin{array}{lr}\text { Starting } & \text { dose } \\
\text { 1/50th } & \text { of } \\
\text { NOAEL } & \text { of } \\
\text { sensitive specie }\end{array}$ & Yes & {$[7]$} \\
\hline $\begin{array}{l}\text { Transcription } \\
\text { factor inhibitor }\end{array}$ & $\begin{array}{l}\text { STAT3 decoy } \\
\text { oligonucleotide }\end{array}$ & $\begin{array}{l}\text { STAT3 } \\
\text { transcription } \\
\text { factor gene } \\
\text { inhibition }\end{array}$ & $\begin{array}{l}\text { Proof-of-mechanism of } \\
\text { action. } \\
\text { To demonstrate } \\
\text { inhibition of STAT3 } \\
\text { target genes (Bcl, Cyclin } \\
\text { D). }\end{array}$ & $\begin{array}{l}\text { Single intra- } \\
\text { tumoral injection } \\
\text { of several doses: } \\
250 \mathrm{mg} / 250 \mathrm{uL} \mathrm{vs} \\
500 \mathrm{mg} / 500 \mathrm{uL} \\
\mathrm{vs} 1000 \mathrm{mg} / 1000 \\
\mathrm{uL}\end{array}$ & Yes & {$[8]$} \\
\hline
\end{tabular}

Abbreviations: MTA (Molecularly Targeted Agents); PD (PharmacoDynamic); MS (Mass Spectrometry); PARP (Poly [ADPribose] polymerase).

modulation accordingly to the drug exposure levels, the objective is to deepen into the proof-of-mechanism anti-tumor activity of the MTA in a cancer stage that is not altered by previous therapies. The main goals are to confirm the biological effect of the MTA and its PK properties, together with validating possible biomarkers that could predict subgroups of patients most likely to benefit. However, no clinical benefit is pursued for the treated patients [30].

WOO trials have been developed in the neo-adjuvant setting [31] but differ from traditional neo-adjuvant trials [32] in the limited treatment duration, the non-therapeutic intent, and the focus on biomarkers of the former MTA in comparison to the use of pathological complete response (pCR) of the latters [33]. Whilst traditional neo-adjuvant trials focus on evaluating the anti-tumor activity of a certain drug by assessing the $\mathrm{pCR}$ rate, WOO studies aim to further characterize the biological activity of the new experimental therapy with $\mathrm{PK} / \mathrm{PD}$ objectives as principal end-points.

WOO studies allow obtaining an unperturbed tissue specimen, appropriate to validate pathway inhibition by the MTA in the same tumor sample and to assess potential compensating feedback loops to better understand crosstalked resistance pathways. WOO studies may represent proof-of-biological efficacy/mechanism studies which serve as an early step before further phase $2 / 3$ proofof-clinical efficacy studies [34]. Basically, WOO neo- adjuvant studies among women with early large primary breast cancers have been performed with this design [6], as depicted in Table 3. As these WOO studies have changed the concept that curable patients may be treated with an experimental drug for interrogating biological questions, breast cancer patients have been considered one of the most feasible settings considering that radical surgery of the primary tumor is often indicated as first therapeutic option.

Interestingly, many WOO studies are usually performed just after the exploration of a MTA in FIH studies. This observation reflects two issues: firstly, that biological activity might be a key aspect in EDD, assisting in go-no go decisions very early in the drug development process. Secondly, curable patients are exposed to experimental MTA that have been previously explored in small cohorts of patients. While this last observation may be due to the relatively favorable profile of these MTA, it also reflects a change in the paradigm of the type of patients enrolled in clinical trials with experimental drugs.

But despite all the advantages that represent the WOO studies, why have they not been routinely implemented for drug development so far? WOO studies have been widely debated, considering the ethical implications involved in delaying upfront standard approved therapies. However, in our opinion, WOO trials emerge as a very useful tool for facilitating the accelerated development program of a certain drug, shortening the 
Table 5: Examples of Healthy Volunteer (HV) studies testing MTA.

\begin{tabular}{|c|c|c|c|c|c|c|}
\hline 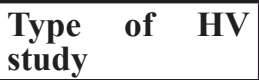 & MTA & $\begin{array}{l}\text { Mechanism of } \\
\text { action }\end{array}$ & $\begin{array}{l}\text { Endpoints of the } \\
\text { study }\end{array}$ & $\begin{array}{l}\text { Healthy subject } \\
\text { dose }\end{array}$ & Status & $\begin{array}{l}\text { ClinicalTrials.gov } \\
\text { identifier }\end{array}$ \\
\hline Drug-drug & $\begin{array}{l}\text { PF-00299804 } \\
\text { (dacomitinib) }\end{array}$ & $\begin{array}{l}\text { Pan-HER } \\
\text { inhibitor }\end{array}$ & $\begin{array}{l}\text { Pharmacokinetic. } \\
\text { To asses } \\
\text { interactions } \\
\text { between } \\
\text { paroxetine and } \\
\text { dacomitinib. } \\
\end{array}$ & $\begin{array}{l}\text { Single doses } 45 \\
\text { mg dacomitinib } \\
\text { with or without } \\
30 \mathrm{mg} \text { paroxetine }\end{array}$ & $\begin{array}{l}\text { Ph1 } \\
\text { completed }\end{array}$ & NCT01318031 \\
\hline Food-drug & $\begin{array}{l}\text { AG-013736 } \\
\text { (axitinib) }\end{array}$ & $\begin{array}{l}\text { VEGFR, } \\
\text { PDGFR, } \\
\text { c-KIT inhibitor }\end{array}$ & $\begin{array}{l}\text { Pharmacokinetic. } \\
\text { To assess the food } \\
\text { effect on drug } \\
\text { levels. }\end{array}$ & $\begin{array}{lr}\text { Single } & \text { doses } \\
\text { axitinib r in } \\
\text { different fasting } \\
\text { conditions }\end{array}$ & $\begin{array}{l}\text { Ph1 } \\
\text { completed }\end{array}$ & NCT00918632 \\
\hline $\begin{array}{l}\text { Cardiovascular } \\
\text { Safety }\end{array}$ & $\begin{array}{l}\text { SOM230 } \\
\text { (pasireotide) }\end{array}$ & $\begin{array}{l}\text { Somatostatin } \\
\text { analogue }\end{array}$ & $\begin{array}{l}\text { Safety. } \\
\text { To assess cardiac } \\
\text { repolarization. }\end{array}$ & $\begin{array}{l}\text { Therapeutic } \\
\text { pasireotide dose } \\
600 \text { ug vs MTD } \\
\text { vs placebo vs } \\
\text { moxifloxacin }\end{array}$ & $\begin{array}{l}\text { Ph1 } \\
\text { completed }\end{array}$ & NCT01128192 \\
\hline Bioavailability & SR13668 & AKT inhibitor & $\begin{array}{l}\text { Pharmacokinetic. } \\
\text { To determine the } \\
\text { best bioavailable } \\
\text { formulation. }\end{array}$ & $\begin{array}{lr}\text { Single } & \text { doses } \\
\text { of } & \text { SR13668 } \\
\text { testing different } \\
\text { formulations }\end{array}$ & $\begin{array}{l}\text { Ph1 } \\
\text { completed }\end{array}$ & NCT00896207 \\
\hline Bioequivalence & PF-05280014 & $\begin{array}{l}\text { Anti-EGFR2 } \\
\text { inhibitor }\end{array}$ & $\begin{array}{l}\text { Pharmacokinetic. } \\
\text { To assess } \\
\text { bioequivalence } \\
\text { between PF- } \\
\text { 05280014 and } \\
\text { approved TTZ. }\end{array}$ & $\begin{array}{l}\text { PF-05280014 vs } \\
\text { TTZ-EU vs TTZ- } \\
\text { US }\end{array}$ & $\begin{array}{l}\text { Ph1 } \\
\text { completed }\end{array}$ & NCT01603264 \\
\hline Ph1 FIH & $\begin{array}{l}\text { ARRY-142866 } \\
\text { (selumetinib) }\end{array}$ & $\begin{array}{l}\text { MEK } 1 / 2 \\
\text { inhibitor }\end{array}$ & $\begin{array}{l}\text { Pharmacokinetic, } \\
\text { safety and } \\
\text { tolerability. }\end{array}$ & $\begin{array}{l}\text { Single doses } \\
\text { of } 25 \text { mg } \\
\text { selumetinib, and } \\
\text { with or without } \\
\text { itraconazol or } \\
\text { fluconazol }\end{array}$ & $\begin{array}{l}\text { Ph1 } \\
\text { completed }\end{array}$ & NCT02093728 \\
\hline
\end{tabular}

Abbreviations: MTA (Molecularly Targeted Agents); HER (Human Epidermal growth factor Receptor); VEGFR (Vascular Endothelial Growth Factor Receptor); PDGFR (Platelet Derived Growth Factor Receptor); MTD (Maximum Tolerated Dose); EGFR2 (Epidermal Growth Factor Receptor 2); TTZ (TrasTuZumab); vs (versus); EU (European Union); US (United States).

laborious process of evaluating a new MTA. As long as safety monitoring and careful candidate pre-selection are performed, WOO studies may optimize and increase the chances of success of a specific MTA from the early beginning, as the failure to achieve the predefined objectives in the study may be a sign for not continuing with its development. Also, it has to be considered that patients included in WOO trials may truly reflect the real intention-to-treat population compared to the heavily pretreated $\mathrm{Ph} 1$ patients. Nevertheless, intense efforts should be done in order to ensure that patients understand the risk/benefit ratio of participating in these clinical trials, to warrant precocious detection of disease progression and to avoid enrolling unfit patients [35]. Maybe because of this risk/benefit ratio, most of the WOO trials testing MTA in the neo-adjuvant setting have included well-known drugs. In reality, as depicted in table 3, very few of them include experimental drugs in early stages of their development, with most of the WOO studies published in the literature examining drugs that are already transitioning to the late development process.
Despite their appealing potential, moving an experimental therapy with a limited long-term toxicity profile experience to the neo-adjuvant setting, with curable untreated patients, may be carefully considered. That is the reason why WOO studies should only be considered and acceptable in populations with a high risk of relapse and a significant unmet medical need (e.g. patients with high grade, hormone receptor positive and HER2-negative breast cancers). It should be kept in mind that not all drugs are suitable for being tested in a WOO trial, as only some drugs with a plausible biological MoA thought to be involved in cancer modulation, with a welldescribed toxicity profile and displaying particular PK/ PD characteristics, can be considered good candidates for being explored in this setting. As example, the oral antidiabetic drug, metformin, is currently moving towards a new classification as a potential cancer metabolismtargeted drug, due to the underlying link between obesity and hyper-insulinemia and breast cancer [36]. However, the clinical translation of metformin as a new anti-cancer therapy has been limited by the lack of PD biomarkers (e.g. 
Ki67 \% or proliferative index) that could translate into an early read out of its biological activity in cancer patients so far. On top of that, as most of the preclinical studies do not have an appropriate PK design, some of the limited results obtained in in vivo and in vitro experiments may be related to the suboptimal doses tested of metformin [37]. One of the strengths of metformin is that its short and longterm toxicity effects are already well-described, and the drug is deemed safe and widely implemented in the daily care of millions of diabetic patients. Testing metformin in a WOO clinical trial design [6] could provide more insights into the clinical PK/PD of the drug in an optimal model that mimics the real patient scenario. The WOO strategy will help to better illustrate its PD mechanism of action (whether the administration of metformin reduces the proliferation of tumoral cells by assessing the Ki67 proliferative index in surgical specimens) and to optimize a relevant and achievable drug concentration in plasma by obtaining detailed PK data. Therefore, the PD/PK data will help in delineating future large scale randomized clinical trials, maximizing the chance of success of metformin as a new anti-cancer strategy.

\section{PHASE 0 STUDIES}

By definition, $\mathrm{Ph} 0$ trials are clinical studies conducted in EDD before the traditional Ph1 studies, to provide human PK and PD data, benefiting EDD by allowing to clinically testing a proposed MoA. They are FIH trials with neither therapeutic nor diagnostic intent, with a low number of patients included and limited drug exposure. Part of the rationale for conducting them is that the new agent promises significant biological effect in a substantial percentage of participants, even at doses below the expected ones that could lead to toxicity [38]. However, several limitations of the $\mathrm{Ph} 0$ have made highly controversial their implementation, such as their intense resource use and complexity, the request of serial tumor biopsies, the requirement of analytical methods that are not routinely available, and specially, the lack of therapeutic purpose for the treated patients [39].

The Ph0 concept implies a change in role of studies in Oncology. In Ph0 studies, candidates assume the role of "sick volunteers" given the absence of any direct efficacy for the participant, closer to the HV concept - see next section- [40]. The main motivator may be altruism for the "benefit to others". Hence, Ph0 trials are both ethically challenged and challenging, since the patient has to understand that clinical benefit is not pursued, and that even if the risks seem low, there is a high degree of uncertainty regarding potential toxicities [41]. Under these circumstances, only patients with advanced incurable malignancies should be recruited after failure of standard therapy or in case that their indolent diseases do not require immediate treatment. Furthermore, not all MTA can be explored within a Ph0 context. Ideally, one must have a minimum of toxicology package and certain knowledge of the PK properties of the drug evaluated. Previous extensive preclinical experiments are required to establish a safe starting dose and schedule, in order to help in predicting the plasmatic levels of the MTA (PD data) that are required for target modulation (PK data) without reaching a therapeutic level [42].

Despite the fact that some experts in EDD consider that such trials will become a routine of the field in the future [42], we could only find few examples of contemporary trials with this design, probably because of the previously mentioned challenges and that similar information can be achieved with the regular $\mathrm{Ph} 1$ trial designs. It is worth noticing that many of them were published as $\mathrm{Ph} 0$ trials, although they do not fulfill the criteria for a Ph0 design, as shown in Table 4. Most of these studies include drugs with a significant clinical experience, which should be called "biomarker-driven" studies. Among the properly Ph0 trials detected, new imaging compounds have been tested, such as the 11C-labeled topoisomerase I/II inhibitor $\mathrm{N}$-[2(dimethylamino)ethyl]acridine-4-carboxamide (DACA) [43]. Ph0 trials could be also focused on determining pharmacologically relevant doses of a certain drug, such as imatinib [44], or they could assess the MoA/PD markers of new compounds, like the ABT-888 [7] or the STAT3 decoy oligonucleotide [8].

Further efforts to improve their design limitations seem mandatory, as they may be a promising field to get data from a new compound in early phases of its development.

\section{HEALTHY VOLUNTEER STUDIES}

Outside the Oncology field, it is common that the introduction of a new drug in patients is tested firstly in HV, limiting human exposure. Designing the appropriate $\mathrm{FIH}$ dose requires close collaboration among the toxicologists and the preclinical scientists, to use modeling data from animal experiments to determine a safe starting dose and a dosing interval [45]. The definition of $\mathrm{HV}$ per se is challenging. The widely accepted definition comprises those healthy, adult volunteers, in well-defined and controlled conditions. However, this definition underlies several margins of discretion regarding the wellness of a patient, and a critical judgment is mandatory when enrolling a candidate. Several ethical concerns arouse in 2006 with The TeGenero incident [46], where TGN1412 caused life-threatening toxicities and fostered the implementation of strict guidelines for EDD. Subsequently, specific rules were developed to guide HV studies [47]. These HV studies should be conducted in units with sufficient expertise, and their usual characteristics include: 1) A single subject receives the first dose within a justified period of observation before the next subject receives another dose, 2) double-blind 
design is preferred to avoid risks of bias, 3) subjects are randomly assigned to receive either the active drug or the placebo/control drug, and 4) different designs are used (parallel, crossover and sequential groups) based on the objectives of the study.

In Oncology, though, most anticancer agents have been tested only in advanced cancer patients assuming their potential severe side effects, mutagenicity and carcinogenesis, accepting higher degrees of toxicity considering that these secondary effects would be less threatening than the disease itself [48]. Interestingly, new MTA have started to be explored in HV studies recently. This is probably based on their relatively broaden safety profile and because these $\mathrm{HV}$ are more able to withstand any unexpected toxicity from these new molecular entities [49]. However, careful consideration must be taken in view of the novelty of their MoA. We may not fully know the exact MoA for a specific MTA by the time we initiate early studies, therefore special attention is required in view of possible interactions between biological cascades. The risk with MTA could emerge not only from their chemical structure but also from their biologic or intended pharmacological mechanisms [50]. As example, some MTA have revealed delayed severe side effects (e.g. pneumonitis with mTOR inhibitors [51, 52]) and many combinations of MTA have proven to be challenging in terms of overlapping toxicities [53, 54].

The types of studies done in HV in Oncology include:

1. Drug-drug and food-drug interaction studies, conducted to investigate what concomitant medications or food/drink products can interfere with the pharmacokinetic characteristics of a tested MTA $[11,12]$.

2. Cardiovascular safety studies are required if the new MTA shows potential cardiovascular

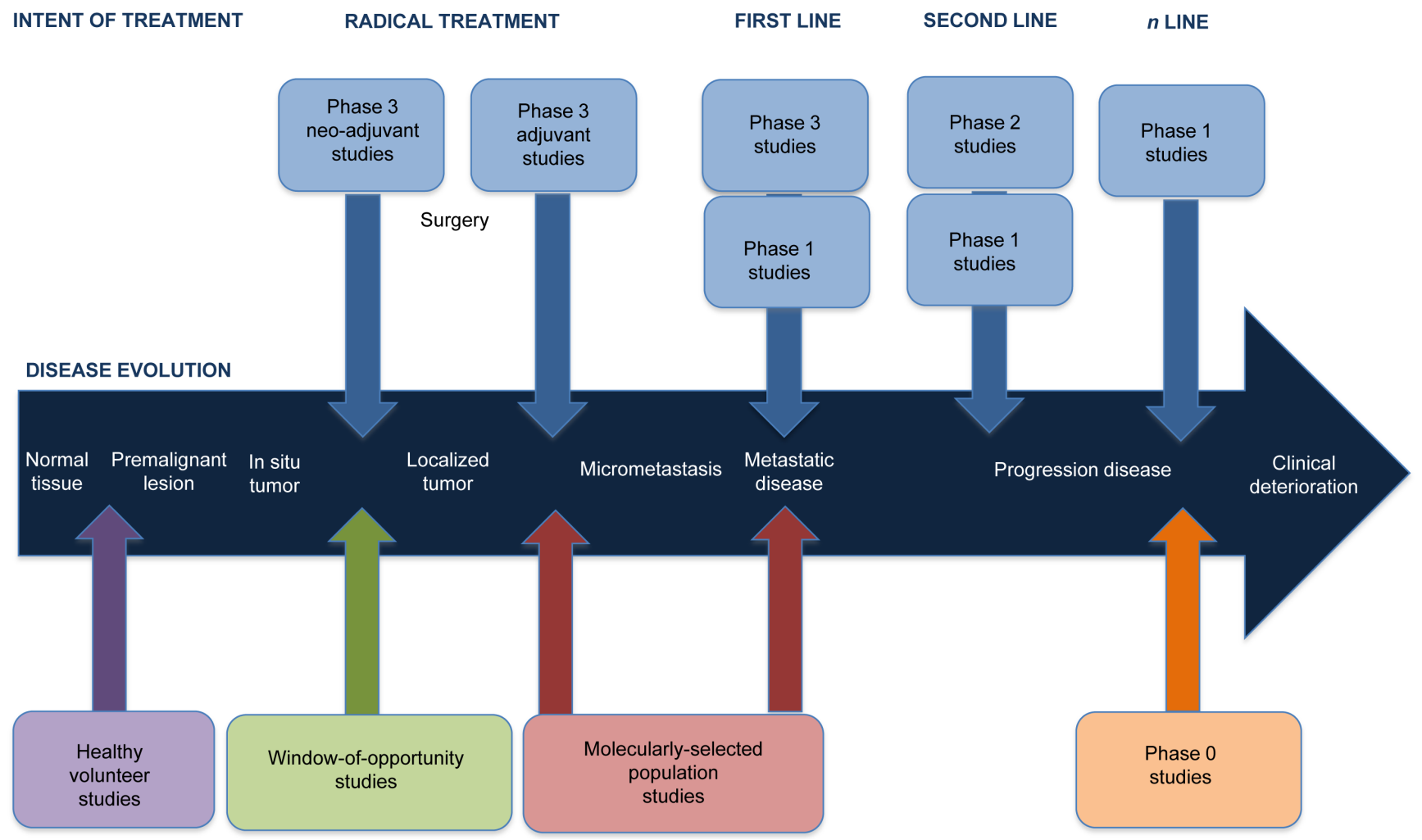

Figure 1: Depicting the journey of a cancer patient through the different new clinical trial designs in the Early Drug Development field. The development of novel Molecularly Targeted Agents (MTA) has lead to the possibility of receiving these anticancer drugs in new patient populations. Noteworthy, one single patient could aim to participate in each one of the four types of studies here depicted throughout the evolution of his/her cancer. Being in good health status, the individual could participate in a Healthy Volunteer (HV) study, sometimes even decades before developing a premalignant lesion. Once diagnosed with an early invasive localized cancer, the patient may be considered candidate for receiving neo-adjuvant therapy according to the gold standard approach. It is in this same neo-adjuvant setting where the patient could consider to participate in a Window-Of-Opportunity (WOO) study, before proceeding with a radical surgery and adjuvancy. Whenever a metastatic disease recurrence occurs, the evaluation of a potential novel cancer biomarker for the tumor may significantly change the standard-of-care. If a predictive biomarker was identified, this patient may be prioritized for participating in a Molecularly Selected Population (MSP) trial, aiming to match the specific molecular aberration with a highly selective MTA. Should this patient progress despite receiving all the standard options, the patient may still be suitable for participating in a Phase 0 $(\mathrm{Ph} 0)$ study for altruism reasons, even if no efficacy was pursuit. 
toxicity in preclinical animal studies, especially changes in the repolarization based on druginduced inhibition of potassium channels $[55,56]$. If feasible, these studies are strongly recommended to perform in $\mathrm{HV}$, with far less inter-subject variability and without interference by any other adjacent comorbidity or concomitant medication.

3. Bioavailability and bioequivalence studies are developed in order to analyze the effect of changes in the physiochemical properties of a drug, like comparing different formulations and dosage forms, or assessing bioequivalence between several medicinal products containing the same active substance [57]. As MTA are complex molecules, the new ones may not be identical although potentially "biosimilar" to the marketed drugs [58].

4. Finally, classical dose-escalation FIH studies in HV pretend to assess safety and tolerability of a new MTA, considering escalating single or multiple doses [59]. These types of studies do not differ from Ph1 studies done in other disciplines, such as in Endocrinology.

Some examples of MTA tested in each subtype of HV studies are represented in Table 5. Remarkably, HV studies imply a substantial change in patient populations in EDD, since HV represent the opposite side of the spectrum compared with the classical refractory cancer patients.

\section{CONCLUSIONS}

The advent of new MTA has broadened the EDD landscape, not only in terms of expanding the portfolio of drugs, but also in changing the candidates exposed to these experimental therapies. It is clear that many different patient populations other than advanced cancer patients are currently exposed to MTA in their early development. Figure 1. Proposes a potential journey of a cancer patient through the conventional available therapies and their sequence, in parallel to the different new clinical trial designs currently available in EDD.

The appearance of these MTA has opened a field of possibilities towards a second paradigm in EDD, facing the physicians with the challenge of reconsidering "the old paradigm" that only heavily pre-treated cancer patients should be included in a FIH study. As MTA have reshaped clinical trials, there is a rising need to revisit the $\mathrm{I} / \mathrm{E}$ criteria, considering that some of these criteria may be disproportionately restrictive and should be tailored to the potential risk/benefit for incurable cancer patients. Other key points would be how to homogenize the molecular preselection criteria for participating into MSP studies and the need of shortening the time of biomarker analysis, how to obtain higher purity tumor samples and how to overcome the intra-tumor heterogeinity. A coordination effort among multiple academic centers seems mandatory to guarantee a suitable patient identification and adequate accrual, especially considering these small patient populations. WOO studies in the neo-adjuvant setting will need to be considered as one of the most suitable arenas for obtaining more robust biomarker information. However, increasing the recruitment in $\mathrm{WOO}, \mathrm{Ph} 0$ and $\mathrm{HV}$ studies, with no therapeutic intent at all, will certainly suppose a challenge for the Oncologists, as they will need to provide a correct comprehension of trial design and its objectives to the patients, ensuring they understand the risks whilst dealing with patient expectations. Physicians should keep in mind that Ph1 trials still need to focus on finding the appropriate dose that can be administered safely, with optimal efficacy and minimal side effects. Even if most Ph1 focus on early efficacy or biomarkers data nowadays, these should not shadow the primary objective of delineating the safety profile of new MTA, key for further development.

In conclusion, the particular toxicity profile of MTA has broaden the therapeutic window of the anticancer agents, although there is still a long way to go, and special caution will need to be taken when new therapeutic options are tested in these new settings. All these studies may represent a promising, fast and cost-effective method for developing new compounds that can overcome the traditional difficult processes for drug approval based on expensive larger randomized trials. Oncology is one of the fields with higher rates of failures at exceptionally high economic costs, a fact that mandates a profound review of the appropriate clinical trial design for regulatory approval of new MTA. MSP, WOO, Ph0 and HV studies may represent an optimal scenario for further progressing in the development of new drugs, in a timely-effective manner and reducing the economic burden for EDD field.

\section{ACKNOWLEDGMENTS}

We do acknowledge Dr. Juan Martin-Liberal for his support in this manuscript.

\section{FUNDINGS}

This research did not receive any specific grant from funding agencies in the public, commercial, or not-forprofit sectors.

\section{FINANCIAL DISCLOSURE}

Jordi Rodon has been member of advisory boards for Novartis, Lilly, Servier, and Oncompass. The other authors declare no competing financial interests. 


\section{REFERENCES}

1. Rodon J. An (only) partially established paradigm of drug development of targeted therapies. European journal of cancer (Oxford, England : 1990). 2014; 50(12):2037-2039.

2. Dienstmann R, Rodon J and Tabernero J. Drug development in the era of personalized oncology: from population-based trials to enrichment and prescreening strategies. American Society of Clinical Oncology educational book / ASCO American Society of Clinical Oncology Meeting. 2012:168172.

3. Postel-Vinay S, Collette L, Paoletti X, Rizzo E, Massard C, Olmos D, Fowst C, Levy B, Mancini P, Lacombe D, Ivy P, Seymour L, Le Tourneau C, et al. Towards new methods for the determination of dose limiting toxicities and the assessment of the recommended dose for further studies of molecularly targeted agents--dose-Limiting Toxicity and Toxicity Assessment Recommendation Group for Early Trials of Targeted therapies, an European Organisation for Research and Treatment of Cancer-led study. European journal of cancer (Oxford, England : 1990). 2014; 50(12):2040-2049.

4. Le Tourneau C, Gan HK, Razak AR and Paoletti X. Efficiency of new dose escalation designs in dose-finding phase I trials of molecularly targeted agents. PloS one. 2012; 7(12):e51039.

5. Hierro C, Rodon J and Tabernero J. Fibroblast Growth Factor (FGF) Receptor/FGF Inhibitors: Novel Targets and Strategies for Optimization of Response of Solid Tumors. Seminars in oncology. 2015; 42(6):801-819.

6. Niraula S, Dowling RJ, Ennis M, Chang MC, Done SJ, Hood N, Escallon J, Leong WL, McCready DR, Reedijk M, Stambolic V and Goodwin PJ. Metformin in early breast cancer: a prospective window of opportunity neoadjuvant study. Breast cancer research and treatment. 2012; 135(3):821-830.

7. Kummar S, Kinders R, Gutierrez ME, Rubinstein L, Parchment RE, Phillips LR, Ji J, Monks A, Low JA, Chen A, Murgo AJ, Collins J, Steinberg SM, et al. Phase 0 clinical trial of the poly (ADP-ribose) polymerase inhibitor ABT-888 in patients with advanced malignancies. Journal of clinical oncology. 2009; 27(16):2705-2711.

8. Sen M, Thomas SM, Kim S, Yeh JI, Ferris RL, Johnson JT, Duvvuri U, Lee J, Sahu N, Joyce S, Freilino ML, Shi H, Li C, et al. First-in-human trial of a STAT3 decoy oligonucleotide in head and neck tumors: implications for cancer therapy. Cancer discovery. 2012; 2(8):694-705.

9. Ferte C, Soria JC and Penel N. Dose-levels and first signs of efficacy in contemporary oncology phase 1 clinical trials. PloS one. 2011; 6(3):e16633.

10. Gupta P, Gupta V and Gupta YK. Phase I clinical trials of anticancer drugs in healthy volunteers: need for critical consideration. Indian journal of pharmacology. 2012; 44(4):540-542.
11. Shumaker R, Aluri J, Fan J, Martinez G, Ren M and Chen K. Evaluation of the effects of formulation and food on the pharmacokinetics of lenvatinib (E7080) in healthy volunteers. International journal of clinical pharmacology and therapeutics. 2014; 52(4):284-291.

12. Sparano BA, Egorin MJ, Parise RA, Walters J, Komazec KA, Redner RL and Beumer JH. Effect of antacid on imatinib absorption. Cancer chemotherapy and pharmacology. 2009; 63(3):525-528.

13. Llovet JM, Ricci S, Mazzaferro V, Hilgard P, Gane E, Blanc JF, de Oliveira AC, Santoro A, Raoul JL, Forner A, Schwartz M, Porta C, Zeuzem S, et al. Sorafenib in advanced hepatocellular carcinoma. The New England journal of medicine. 2008; 359(4):378-390.

14. Motzer RJ, Hutson TE, Tomczak P, Michaelson MD, Bukowski RM, Oudard S, Negrier S, Szczylik C, Pili R, Bjarnason GA, Garcia-del-Muro X, Sosman JA, Solska E, et al. Overall survival and updated results for sunitinib compared with interferon alfa in patients with metastatic renal cell carcinoma. Journal of clinical oncology. 2009; 27(22):3584-3590.

15. Tokuda Y, Watanabe T, Omuro Y, Ando M, Katsumata N, Okumura A, Ohta M, Fujii H, Sasaki Y, Niwa T and Tajima T. Dose escalation and pharmacokinetic study of a humanized anti-HER2 monoclonal antibody in patients with HER2/neu-overexpressing metastatic breast cancer. British journal of cancer. 1999; 81(8):1419-1425.

16. Baselga J, Rischin D, Ranson M, Calvert H, Raymond E, Kieback DG, Kaye SB, Gianni L, Harris A, Bjork T, Averbuch SD, Feyereislova A, Swaisland H, et al. Phase I safety, pharmacokinetic, and pharmacodynamic trial of ZD1839, a selective oral epidermal growth factor receptor tyrosine kinase inhibitor, in patients with five selected solid tumor types. Journal of clinical oncology. 2002; 20(21):4292-4302.

17. Falchook GS, Long GV, Kurzrock R, Kim KB, Arkenau TH, Brown MP, Hamid O, Infante JR, Millward M, Pavlick AC, O'Day SJ, Blackman SC, Curtis CM, et al. Dabrafenib in patients with melanoma, untreated brain metastases, and other solid tumours: a phase 1 dose-escalation trial. Lancet. 2012; 379(9829):1893-1901.

18. Camidge DR, Bang YJ, Kwak EL, Iafrate AJ, VarellaGarcia M, Fox SB, Riely GJ, Solomon B, Ou SH, Kim DW, Salgia R, Fidias P, Engelman JA, et al. Activity and safety of crizotinib in patients with ALK-positive non-small-cell lung cancer: updated results from a phase 1 study. The Lancet Oncology. 2012; 13(10):1011-1019.

19. Normanno N, Rachiglio AM, Roma C, Fenizia F, Esposito C, Pasquale R, La Porta ML, Iannaccone A, Micheli F, Santangelo M, Bergantino F, Costantini S and De Luca A. Molecular diagnostics and personalized medicine in oncology: challenges and opportunities. Journal of cellular biochemistry. 2013; 114(3):514-524.

20. Carden CP, Sarker D, Postel-Vinay S, Yap TA, Attard G, Banerji U, Garrett MD, Thomas GV, Workman P, Kaye 
SB and de Bono JS. Can molecular biomarker-based patient selection in Phase I trials accelerate anticancer drug development? Drug discovery today. 2010; 15(3-4):88-97.

21. Kwak EL, Bang YJ, Camidge DR, Shaw AT, Solomon B, Maki RG, Ou SH, Dezube BJ, Janne PA, Costa DB, Varella-Garcia M, Kim WH, Lynch TJ, et al. Anaplastic lymphoma kinase inhibition in non-small-cell lung cancer. The New England journal of medicine. 2010; 363(18):16931703.

22. Kim D-W AM-J, Shi Y, et al. Results of a global phase II study with crizotinib in advanced ALK-positive nonsmall cell lung cancer (NSCLC). Poster presented at the 48th annual meeting of the American society of clinical oncology (ASCO) 2012 [Abstract 7533]. 2012.

23. Shaw AT, Kim DW, Mehra R, Tan DS, Felip E, Chow LQ, Camidge DR, Vansteenkiste J, Sharma S, De Pas T, Riely GJ, Solomon BJ, Wolf J, et al. Ceritinib in ALK-rearranged non-small-cell lung cancer. The New England journal of medicine. 2014; 370(13):1189-1197.

24. Maria Clemence Schwaederle MMZ, J. Jack Lee, Vladimir Lazar, Brian Leyland-Jones, Richard L. Schilsky, John Mendelsohn, Razelle Kurzrock. Impact of precision medicine in refractory malignancies: A meta-analysis of 13,203 patients in phase I clinical trials. J Clin Oncol 34, 2016 (suppl; abstr 11520). 2016.

25. de Gramont A, Watson S, Ellis LM, Rodon J, Tabernero J, de Gramont A and Hamilton SR. Pragmatic issues in biomarker evaluation for targeted therapies in cancer. Nature reviews Clinical oncology. 2015; 12(4):197-212.

26. Dancey JE, Dobbin KK, Groshen S, Jessup JM, Hruszkewycz AH, Koehler M, Parchment R, Ratain MJ, Shankar LK, Stadler WM, True LD, Gravell A and Grever MR. Guidelines for the development and incorporation of biomarker studies in early clinical trials of novel agents. Clinical cancer research. 2010; 16(6):1745-1755.

27. Tchekmedyian N, Ali SM, Miller VA and Haura EB. Acquired ALK L1152R Mutation Confers Resistance to Ceritinib and Predicts Response to Alectinib. Journal of thoracic oncology. 2016.

28. Lee JW, Devanarayan V, Barrett YC, Weiner R, Allinson J, Fountain S, Keller S, Weinryb I, Green M, Duan L, Rogers JA, Millham R, O'Brien PJ, et al. Fit-for-purpose method development and validation for successful biomarker measurement. Pharmaceutical research. 2006; 23(2):312328.

29. Gerlinger M, Rowan AJ, Horswell S, Larkin J, Endesfelder D, Gronroos E, Martinez P, Matthews N, Stewart A, Tarpey P, Varela I, Phillimore B, Begum S, et al. Intratumor heterogeneity and branched evolution revealed by multiregion sequencing. The New England journal of medicine. 2012; 366(10):883-892.

30. Kalinsky K and Hershman DL. Cracking open window of opportunity trials. Journal of clinical oncology. 2012; 30(21):2573-2575.
31. Funt SA and Chapman PB. The Role of Neoadjuvant Trials in Drug Development for Solid Tumors. Clinical cancer research. 2016.

32. Romero Q, Bendahl PO, Klintman M, Loman N, Ingvar C, Ryden L, Rose C, Grabau D and Borgquist S. Ki67 proliferation in core biopsies versus surgical samples - a model for neo-adjuvant breast cancer studies. BMC cancer. $2011 ; 11: 341$.

33. Dowsett M, Smith I, Robertson J, Robison L, Pinhel I, Johnson L, Salter J, Dunbier A, Anderson H, Ghazoui Z, Skene T, Evans A, A'Hern R, et al. Endocrine therapy, new biologicals, and new study designs for presurgical studies in breast cancer. Journal of the National Cancer Institute Monographs. 2011; 2011(43):120-123.

34. Metzger-Filho $\mathrm{O}$ and de Azambuja E. Neoadjuvant chemotherapy and targeted therapies: a promising strategy. Journal of the National Cancer Institute Monographs. 2011; 2011(43):116-119.

35. Glimelius B and Lahn M. Window-of-opportunity trials to evaluate clinical activity of new molecular entities in oncology. Annals of oncology. 2011; 22(8):1717-1725.

36. Menendez JA, Martin-Castillo B and Joven J. Metformin and cancer: Quo vadis et cui bono? Oncotarget. 2016; 7:54096-54101. doi: 10.18632/oncotarget.10262.

37. Brown K and Rufini A. New concepts and challenges in the clinical translation of cancer preventive therapies: the role of pharmacodynamic biomarkers. Ecancermedicalscience. 2015; 9:601.

38. Doroshow JH and Parchment RE. Oncologic phase 0 trials incorporating clinical pharmacodynamics: from concept to patient. Clinical cancer research. 2008; 14(12):3658-3663.

39. Murgo AJ, Kummar S, Rubinstein L, Gutierrez M, Collins J, Kinders R, Parchment RE, Ji J, Steinberg SM, Yang SX, Hollingshead M, Chen A, Helman L, et al. Designing phase 0 cancer clinical trials. Clinical cancer research. 2008; 14(12):3675-3682.

40. Kinders R, Parchment RE, Ji J, Kummar S, Murgo AJ, Gutierrez M, Collins J, Rubinstein L, Pickeral O, Steinberg SM, Yang S, Hollingshead M, Chen A, et al. Phase 0 clinical trials in cancer drug development: from FDA guidance to clinical practice. Molecular interventions. 2007; 7(6):325-334.

41. Abdoler E, Taylor $\mathrm{H}$ and Wendler D. The ethics of phase 0 oncology trials. Clinical cancer research. 2008; 14(12):3692-3697.

42. Kummar S, Kinders R, Rubinstein L, Parchment RE, Murgo AJ, Collins J, Pickeral O, Low J, Steinberg SM, Gutierrez M, Yang S, Helman L, Wiltrout R, et al. Compressing drug development timelines in oncology using phase ' 0 ' trials. Nature reviews Cancer. 2007; 7(2):131-139.

43. Saleem A, Aboagye EO, Matthews JC and Price PM. Plasma pharmacokinetic evaluation of cytotoxic agents radiolabelled with positron emitting radioisotopes. Cancer chemotherapy and pharmacology. 2008; 61(5):865-873. 
44. Boddy AV, Sludden J, Griffin MJ, Garner C, Kendrick J, Mistry P, Dutreix C, Newell DR and O'Brien SG. Pharmacokinetic investigation of imatinib using accelerator mass spectrometry in patients with chronic myeloid leukemia. Clinical cancer research. 2007; 13(14):41644169.

45. U.S. Department of Health and Human Services. Food and drug Administration (FDA) CfDEaRC. (July 2005). Guidance for Industry: Estimating the maximum safe starting dose in initial clinical trials for therapeutics in adult healthy volunteers.

46. Suntharalingam G, Perry MR, Ward S, Brett SJ, CastelloCortes A, Brunner MD and Panoskaltsis N. Cytokine storm in a phase 1 trial of the anti-CD28 monoclonal antibody TGN1412. The New England journal of medicine. 2006; 355(10):1018-1028.

47. (CHMP) EMAECfMPfHU. (July 2008). ICH Topic M3(R2). Non-Clinical Safety Studies for the Conduct of Human Clinical Trials and Marketing Authorization for Pharmaceuticals.

48. Senderowicz AM. Information needed to conduct first-inhuman oncology trials in the United States: a view from a former FDA medical reviewer. Clinical cancer research. 2010; 16(6):1719-1725.

49. Pasqualetti G, Gori G, Blandizzi C and Del Tacca M. Healthy volunteers and early phases of clinical experimentation. European journal of clinical pharmacology. 2010; 66(7):647-653.

50. Emanuel EJ, Bedarida G, Macci K, Gabler NB, Rid A and Wendler D. Quantifying the risks of non-oncology phase I research in healthy volunteers: meta-analysis of phase I studies. BMJ (Clinical research ed). 2015; 350:h3271.

51. Zhang X, Ran YG and Wang KJ. Risk of mTOR inhibitors induced severe pneumonitis in cancer patients: a metaanalysis of randomized controlled trials. Future oncology (London, England). 2016.

52. Willemsen AE, Grutters JC, Gerritsen WR, van Erp NP, van Herpen CM and Tol J. mTOR inhibitor-induced interstitial lung disease in cancer patients: Comprehensive review and a practical management algorithm. International journal of cancer. 2016; 138(10):2312-2321.

53. Kummar S, Chen HX, Wright J, Holbeck S, Millin MD, Tomaszewski J, Zweibel J, Collins J and Doroshow JH. Utilizing targeted cancer therapeutic agents in combination: novel approaches and urgent requirements. Nature reviews Drug discovery. 2010; 9(11):843-856.

54. Wong CH, Ma BB, Cheong HT, Hui CW, Hui EP and Chan AT. Preclinical evaluation of PI3K inhibitor BYL719 as a single agent and its synergism in combination with cisplatin or MEK inhibitor in nasopharyngeal carcinoma (NPC). American journal of cancer research. 2015; 5(4):1496-1506.

55. Parkinson J, Visser SA, Jarvis P, Pollard C, Valentin JP, Yates JW and Ewart L. Translational pharmacokineticpharmacodynamic modeling of QTc effects in dog and human. Journal of pharmacological and toxicological methods. 2013; 68(3):357-366.

56. Caruso A, Frances N, Meille C, Greiter-Wilke A, Hillebrecht A and Lave T. Translational PK/PD modeling for cardiovascular safety assessment of drug candidates: Methods and examples in drug development. Journal of pharmacological and toxicological methods. 2014; 70(1):73-85.

57. Xu H, O'Gorman M, Boutros T, Brega N, Kantaridis C, Tan W and Bello A. Evaluation of crizotinib absolute bioavailability, the bioequivalence of three oral formulations, and the effect of food on crizotinib pharmacokinetics in healthy subjects. Journal of clinical pharmacology. 2014.

58. Khraishi M, Stead D, Lukas M, Scotte F and Schmid H. Biosimilars: A Multidisciplinary Perspective. Clinical therapeutics. 2016.

59. Saito K, Nagashima H, Noguchi K, Yoshisue K, Yokogawa T, Matsushima E, Tahara T and Takagi S. First-in-human, phase I dose-escalation study of single and multiple doses of a first-in-class enhancer of fluoropyrimidines, a dUTPase inhibitor (TAS-114) in healthy male volunteers. Cancer chemotherapy and pharmacology. 2014; 73(3):577-583.

60. Burris HA, 3rd, Hurwitz HI, Dees EC, Dowlati A, Blackwell KL, O’Neil B, Marcom PK, Ellis MJ, Overmoyer B, Jones SF, Harris JL, Smith DA, Koch KM, et al. Phase I safety, pharmacokinetics, and clinical activity study of lapatinib (GW572016), a reversible dual inhibitor of epidermal growth factor receptor tyrosine kinases, in heavily pretreated patients with metastatic carcinomas. Journal of clinical oncology. 2005; 23(23):5305-5313.

61. Geyer CE, Forster J, Lindquist D, Chan S, Romieu CG, Pienkowski T, Jagiello-Gruszfeld A, Crown J, Chan A, Kaufman B, Skarlos D, Campone M, Davidson N, et al. Lapatinib plus capecitabine for HER2-positive advanced breast cancer. The New England journal of medicine. 2006; 355(26):2733-2743.

62. Agus DB, Gordon MS, Taylor C, Natale RB, Karlan B, Mendelson DS, Press MF, Allison DE, Sliwkowski MX, Lieberman G, Kelsey SM and Fyfe G. Phase I clinical study of pertuzumab, a novel HER dimerization inhibitor, in patients with advanced cancer. Journal of clinical oncology. 2005; 23(11):2534-2543.

63. Baselga J, Cortes J, Kim SB, Im SA, Hegg R, Im YH, Roman L, Pedrini JL, Pienkowski T, Knott A, Clark E, Benyunes MC, Ross G, et al. Pertuzumab plus trastuzumab plus docetaxel for metastatic breast cancer. The New England journal of medicine. 2012; 366(2):109-119.

64. van Oosterom AT, Judson I, Verweij J, Stroobants S, Donato di Paola E, Dimitrijevic S, Martens M, Webb A, Sciot R, Van Glabbeke M, Silberman S and Nielsen OS. Safety and efficacy of imatinib (STI571) in metastatic gastrointestinal stromal tumours: a phase I study. Lancet. 2001; 358(9291):1421-1423.

65. Blanke CD, Rankin C, Demetri GD, Ryan CW, von Mehren 
M, Benjamin RS, Raymond AK, Bramwell VH, Baker LH, Maki RG, Tanaka M, Hecht JR, Heinrich MC, et al. Phase III randomized, intergroup trial assessing imatinib mesylate at two dose levels in patients with unresectable or metastatic gastrointestinal stromal tumors expressing the kit receptor tyrosine kinase: S0033. Journal of clinical oncology. 2008; 26(4):626-632.

66. Verweij J, Casali PG, Zalcberg J, LeCesne A, Reichardt P, Blay JY, Issels R, van Oosterom A, Hogendoorn PC, Van Glabbeke M, Bertulli R and Judson I. Progression-free survival in gastrointestinal stromal tumours with high-dose imatinib: randomised trial. Lancet. 2004; 364(9440):11271134.

67. Blay JY, Le Cesne A, Ray-Coquard I, Bui B, Duffaud F, Delbaldo C, Adenis A, Viens P, Rios M, Bompas E, Cupissol D, Guillemet C, Kerbrat P, et al. Prospective multicentric randomized phase III study of imatinib in patients with advanced gastrointestinal stromal tumors comparing interruption versus continuation of treatment beyond 1 year: the French Sarcoma Group. Journal of clinical oncology. 2007; 25(9):1107-1113.

68. Hidalgo M, Siu LL, Nemunaitis J, Rizzo J, Hammond LA, Takimoto C, Eckhardt SG, Tolcher A, Britten CD, Denis L, Ferrante K, Von Hoff DD, Silberman S, et al. Phase I and pharmacologic study of OSI-774, an epidermal growth factor receptor tyrosine kinase inhibitor, in patients with advanced solid malignancies. Journal of clinical oncology. 2001; 19(13):3267-3279.

69. Rosell R, Carcereny E, Gervais R, Vergnenegre A, Massuti B, Felip E, Palmero R, Garcia-Gomez R, Pallares C, Sanchez JM, Porta R, Cobo M, Garrido P, et al. Erlotinib versus standard chemotherapy as first-line treatment for European patients with advanced EGFR mutation-positive non-small-cell lung cancer (EURTAC): a multicentre, open-label, randomised phase 3 trial. The Lancet Oncology. 2012; 13(3):239-246.

70. Mok TS, Wu YL, Thongprasert S, Yang CH, Chu DT, Saijo N, Sunpaweravong P, Han B, Margono B, Ichinose Y, Nishiwaki Y, Ohe Y, Yang JJ, et al. Gefitinib or carboplatin-paclitaxel in pulmonary adenocarcinoma. The New England journal of medicine. 2009; 361(10):947-957.

71. Fong PC, Boss DS, Yap TA, Tutt A, Wu P, MerguiRoelvink M, Mortimer P, Swaisland H, Lau A, O'Connor MJ, Ashworth A, Carmichael J, Kaye SB, et al. Inhibition of poly(ADP-ribose) polymerase in tumors from BRCA mutation carriers. The New England journal of medicine. 2009; 361(2):123-134.

72. Audeh MW, Carmichael J, Penson RT, Friedlander M, Powell B, Bell-McGuinn KM, Scott C, Weitzel JN, Oaknin A, Loman N, Lu K, Schmutzler RK, Matulonis U, et al. Oral poly(ADP-ribose) polymerase inhibitor olaparib in patients with BRCA1 or BRCA2 mutations and recurrent ovarian cancer: a proof-of-concept trial. Lancet. 2010; 376(9737):245-251.

73. Flaherty KT, Puzanov I, Kim KB, Ribas A, McArthur GA,
Sosman JA, O’Dwyer PJ, Lee RJ, Grippo JF, Nolop K and Chapman PB. Inhibition of mutated, activated BRAF in metastatic melanoma. The New England journal of medicine. 2010; 363(9):809-819.

74. Chapman PB, Hauschild A, Robert C, Haanen JB, Ascierto P, Larkin J, Dummer R, Garbe C, Testori A, Maio M, Hogg D, Lorigan P, Lebbe C, et al. Improved survival with vemurafenib in melanoma with BRAF V600E mutation. The New England journal of medicine. 2011; 364(26):25072516.

75. Hauschild A, Grob JJ, Demidov LV, Jouary T, Gutzmer R, Millward M, Rutkowski P, Blank CU, Miller WH, Jr., Kaempgen E, Martin-Algarra S, Karaszewska B, Mauch C, et al. Dabrafenib in BRAF-mutated metastatic melanoma: a multicentre, open-label, phase 3 randomised controlled trial. Lancet. 2012; 380(9839):358-365.

76. Fabrice Andre MR, Emma Dean, Andrea Varga, Ruud van der Noll, Paul K. Stockman, Dana Ghiorghiu, Elaine Kilgour, Paul D. Smith, Merran Macpherson, Peter Lawrence, Andrew Hastie, Jan HM Schellens. Abstract LB145: Results of a phase I study of AZD4547, an inhibitor of fibroblast growth factor receptor (FGFR), in patients with advanced solid tumors. AACR 104th Annual Meeting 2013; Apr 6-10, 2013; Washington, DC. 2013.

77. Hendrik-Tobias Arkenau MS, Antoine Hollebecque, Alastair Mathewson, Charlotte Rose and Lemech DL, Paul Frewer, Elaine Kilgour, Nigel Brooks;. A phase 1 expansion cohort of the fibroblast growth factor receptor (FGFR) inhibitor AZD4547 in patients (pts) with advanced gastric (GC) and gastroesophageal (GOJ) cancer. J Clin Oncol 32:5s, 2014 (suppl; abstr 2620). 2014.

78. Paul K. Paik RS, David Ferry, Jean-Charles Soria, Alastair Mathewson, Elaine Kilgour, Donal and Landers PF, Nigel Brooks, Fabrice Andre. A phase 1b open-label multicenter study of AZD4547 in patients with advanced squamous cell lung cancers: Preliminary antitumor activity and pharmacodynamic data. J Clin Oncol 32:5s, 2014 (suppl; abstr 8035). 2014.

79. Lecia V. Sequist PC, Andrea Varga, Josep Tabernero, Jan H. Schellens, Jean-Pierre Delord, Patricia LoRusso, D. Ross Camidge, Manuel Hidalgo Medina, Martin Schuler, Mario Campone, G. Gary Tian, Steven Wong, Jesus Corral, Randi Isaacs, Suman K. Sen, Diana Graus Porta, Swarupa G. Kulkarni, Caroline Lefebvre, and Jürgen Wolf. Phase I study of BGJ398, a selective pan-FGFR inhibitor in genetically preselected advanced solid tumors. Proceedings: AACR Annual Meeting 2014; April 5-9, 2014; San Diego, CA. 2014.

80. Tabernero J, Bahleda R, Dienstmann R, Infante JR, Mita A, Italiano A, Calvo E, Moreno V, Adamo B, Gazzah A, Zhong B, Platero SJ, Smit JW, et al. Phase I DoseEscalation Study of JNJ-42756493, an Oral Pan-Fibroblast Growth Factor Receptor Inhibitor, in Patients With Advanced Solid Tumors. Journal of clinical oncology. 2015; 33(30):3401-3408. 
81. Yung-Jue Bang W-CS, Do-Hyun Nam, Wan-Teck Lim, Todd Michael Bauer, Irene Brana, Ronnie Tung-Ping Poon DSH, Chia-Chi Lin, Bin Peng, Yingxi Zhang, Sylvia Zhao, Arun and Kumar MA, Brigette Ma. Phase I study of the safety and efficacy of INC280 in patients with advanced MET-dependent solid tumors. J Clin Oncol 32:5s, 2014 (suppl; abstr 2520^). 2014.

82. Eric Angevin GS, Antoine Hollebecque, Tommaso De Pas, Jean-Charles Soria, Marzia and Harnois FM, Sylvie Assadourian, Filippo De Marinis. A first-in-human (FIH) phase I study of SAR125844, a novel selective MET kinase inhibitor, in patients (pts) with advanced solid tumors: Dose escalation results. J Clin Oncol 32:5s, 2014 (suppl; abstr 2506). 2014.

83. Janne PA, Boss DS, Camidge DR, Britten CD, Engelman JA, Garon EB, Guo F, Wong S, Liang J, Letrent S, Millham R, Taylor I, Eckhardt SG, et al. Phase I dose-escalation study of the pan-HER inhibitor, PF299804, in patients with advanced malignant solid tumors. Clinical cancer research. 2011; 17(5):1131-1139.

84. Soria JC, DeBraud F, Bahleda R, Adamo B, Andre F, Dienstmann R, Delmonte A, Cereda R, Isaacson J, Litten J, Allen A, Dubois F, Saba C, et al. Phase I/IIa study evaluating the safety, efficacy, pharmacokinetics, and pharmacodynamics of lucitanib in advanced solid tumors. Annals of oncology. 2014; 25(11):2244-2251.

85. D. Juric HB, M. Schuler, J.Schellens, J. Berlin, R. Seggewiß-Bernhardt, M. Gil-Martin, A. Gupta, J.Rodon, J. Tabernero, F.Janku, H.S.Rugo, D. Bootle, C. Quadt, C.Coughlin, D. Demanse, L.Blumenstein, J. Baselga. Phase I/IIa study evaluating the safety, efficacy, pharmacokinetics, and pharmacodynamics of lucitanib in advanced solid tumors. Annals of Oncology (2014) 25 (suppl_4):

iv146-iv164. 2014.

86. Rodon J, Brana I, Siu LL, De Jonge MJ, Homji N, Mills D, Di Tomaso E, Sarr C, Trandafir L, Massacesi C, Eskens $\mathrm{F}$ and Bendell JC. Phase I dose-escalation and -expansion study of buparlisib (BKM120), an oral pan-Class I PI3K inhibitor, in patients with advanced solid tumors. Investigational new drugs. 2014; 32(4):670-681.

87. Reinhard Dummer CR, Marta Nyakas, Grant A. McArthur, Ragini Reiney Kudchadkar,, Carlos Gomez-Roca RJS, Keith Flaherty, Carla Murer, Daniela Michel, Zhongwen Tang, and Laure A. De Parseval J-PD. Initial results from a phase I, open-label, dose escalation study of the oral BRAF inhibitor LGX818 in patients with BRAF V600 mutant advanced or metastatic melanoma. J Clin Oncol 31, 2013 (suppl; abstr 9028). 2013.

88. C.A. Gomez-Roca JD, C. Robert,M. Hidalgo, R. von Moos, A. Arance, E.Elez, D. Michel, A. Seroutou, T.Demuth, J. Tabernero. Encorafenib (LGX818), an oral BRAF inhibitor, in patients (pts) with BRAF V600E metastatic colorectal cancer (MCRC): results of dose expansion in an open-label, phase I study. Annals of Oncology (2014) 25 (suppl_4):iv167-iv209. 2014.
89. Johanna C. Bendell KP, Suzanne F. Jones, Emma Barrett, Kari Guthrie, Carrie L. Kass, Kevin S. Litwiler, Cheryl Napier, and Amita Patnaik. A phase I dose-escalation study of MEK inhibitor MEK162 (ARRY-438162) in patients with advanced solid tumors. Mol Cancer Ther November 2011 10; B243. 2011.

90. Fong PC, Yap TA, Boss DS, Carden CP, Mergui-Roelvink M, Gourley C, De Greve J, Lubinski J, Shanley S, Messiou C, A'Hern R, Tutt A, Ashworth A, et al. Poly(ADP)ribose polymerase inhibition: frequent durable responses in BRCA carrier ovarian cancer correlating with platinum-free interval. Journal of clinical oncology. 2010; 28(15):25122519.

91. Johann Sebastian De Bono LAM, Michael Gonzalez, Nicola J. Curtin, Evelyn Wang, Joshua, W. Henshaw MC, Jasgit C. Sachdev, Daniela Matei, Gayle S. Jameson, Michael Ong, Bristi Basu ZAW, Lauren Averett Byers, Rashmi Chugh, Andrew Dorr, Stanley B. Kaye, and Ramanathan. RK. Firstin-human trial of novel oral PARP inhibitor BMN 673 in patients with solid tumors. J Clin Oncol 31, 2013 (suppl; abstr 2580). 2013.

92. Leora Horn JRI, George R. Blumenschein, Heather A. Wakelee, Hendrik-Tobias, Arkenau GD, Chris Liang, Kimberly Harrow, Jay Gibbons, Christine Marie Lovly, William and Pao. A phase I trial of X-396, a novel ALK inhibitor, in patients with advanced solid tumors. J Clin Oncol 32:5s, 2014 (suppl; abstr 8030^). 2014.

93. F.G.M. De Braud LP, M. Niger, S.Damian, B. Bardazza, A. Martinetti, G.Pelosi, G. Marrapese, L. Palmeri, G.Cerea, E. Valtorta, S. Veronese, A.Sartore-Bianchi, E. Ardini, M.Martignoni, A. Isacchi, P. Pearson, D.Luo, J.L. Freddo, S. Siena. RXDX-101, an oral Pan-Trk, ROS1, and ALK inhibitor, in patients with advanced solid tumors with relevant molecular alterations. Annals of Oncology (2014) 25 (suppl_4): iv146-iv164. 2014.

94. K. Kalinsky JAS, M. Kim, K. D. Crew, M. A. Maurer, B. Taback, S. M. Feldman, H. Hibshoosh, L. Wiechmann, K. B. Adelson, D. L. Hershman. Presurgical evaluation of the AKT inhibitor MK-2206 in patients with operable invasive breast cancer. J Clin Oncol 29: 2011 (suppl; abstr TPS147). 2011.

95. Chi KN, Gleave ME, Fazli L, Goldenberg SL, So A, Kollmannsberger C, Murray N, Tinker A and Pollak M. A phase II pharmacodynamic study of preoperative figitumumab in patients with localized prostate cancer. Clinical cancer research. 2012; 18(12):3407-3413. 